УДК 616.12-007.2-053.2-036.882-08

\title{
Раннє ентеральне харчування в післяопераційному періоді та його вплив на активізацію дітей до 1 року після кардіохірургічних операцій
}

\author{
Якімішен О. О., Бойко С. М., Хеміо Арнес С. Г., Мошківська Л. В., Труба Я. П., \\ Лазоришинець В.В.
}

ДУ «Національний інститут серцево-судинної хірургії імені М. М. Амосова НАМН» (Київ)

\begin{abstract}
Мета дослідження - визначення характеру перебігу післяопераційного періоду у кардіохірургічних пацієнтів віком до 1 року залежно від часу початку ентерального харчування. Методи. Проведено ретроспективне дослідження двох груп дітей віком до 1 року, у яких ентеральне харчування розпочато через 24 години (група 1) і через 6 годин (група 2) після операції на серці. Критеріями оцінки були біохімічні показники, перебіг післяопераційного періоду та час перебування в палаті інтенсивної терапії. Результати. Суттєві катаболічні зміни виявлено в першій групі (з пізнім початком ентерального харчування). Перебіг післяопераційного періоду був більш сприятливим, час перебування в палаті інтенсивної терапії - меншим, ніж у другій групі. Висновки. Раннє ентеральне харчування зменшує ризик розвитку післяопераційних респіраторних ускладнень, частоту зміни антибактеріальної терапії, призначення альбуміну та скорочує час активізації пацієнтів після операцій на серці з екстракорпоральним кровообігом.
\end{abstract}

Ключові слова: ентеральне харчування, новонароджені, вроджені вади серия, кардіохірургічні операції, штучний кровообіг.

Вроджена вада серця (ВВС), спричиняючи низку змін, у першу чергу компенсаторного характеру, є системним захворюванням усього організму [1]. Аномалії розвитку серця та магістральних судин призводять до різних порушень гемодинаміки, які поділяються на первинні, що виникають відразу після народження дитини, i вторинні, які $є$ наслідком перебігу вродженої вади серця.

Розвиток кардіохірургії дозволив суттєво знизити госпітальну летальність після операцій на серці зі штучним кровообігом у дітей. Але такі процеси, як хронічна гіпоксія і порушення кровообігу, під впливом нейрогуморальних факторів призводять до компенсаторної перебудови всіх систем і органів. Серцево-судинна недостатність, розвиток легеневої гіпертензії або гіповолемії малого кола кровообігу прогресують із кожним місяцем життя дитини і сприяють розвитку загальних патофізіологічних синдромів. У дітей раннього віку з вродженою вадою серця переважними скаргами при зборі анамнезу є поганий апетит і недостатне збільшення маси тіла, а під час обстеження в кардіохірургічному стаціонарі досить часто як супутній діагноз виявляється дистрофія типу гіпотрофії 1-2 ступеня [2].

Гіпотрофія в ранньому післяопераційному періоді призводить до серйозних порушень метаболізму та імунного статусу, що значною мірою знижує ефективність лікування пацієнтів, збільшує тривалість їх госпіталізації у відділенні інтенсивної терапії та пов'язані з цим витрати на лікування. Виявилося, що харчова підтримка, методами якої є ентеральне і парентеральне харчування, має зайняти своє місце поряд із респіраторною, інфузійною та інотропною підтримкою, раціональною антибактеріальною терапією [3].

При лікуванні вроджених вад серця з використанням екстракорпорального кровообігу в післяопераційному періоді переважає катаболічна спрямованість процесів метаболізму [4]. Американське (American Society for Parenteral and Enteral Nutrition - ASPEN) i $\mathrm{C}_{\mathrm{B}}$ ропейське (ESPEN) товариства парентерального та ентерального харчування рекомендують починати ентеральне харчування раніше (в перші 24-48 годин) після стабілізації стану хворого [5].

Ентеральні суміші на основі повністю гідролізованих сироваткових білків легко перетравлюються і добре засвоюються організмом. Вони знижують частоту функціональних порушень травлення, сприяють нормалізації випорожнень, покращують вісцеральний синтез білка. Високий вміст цистеїну в сумішах сприяе поповненню запасів глутатіону, тим самим підтримуючи антиоксидантний та імунний статус дитини.

Спеціалізовані суміші для лікувального ентерального харчування дитини в ранньому післяопераційному періоді повинні повністю засвоюватися і не спричиняти кишкової перистальтики, що зумовлюється відсутністю в них баластних речовин і лактози, мінімально стимулювати жовчо- і соковиділення. Суміші мають містити повний комплекс вітамінів і мікроелементів, що робить можливим застосування препарату протягом тривалого періоду [6]. 


\section{Таблиця 1}

Анатомічна характеристика вроджених вад серия у обстежених групах

\begin{tabular}{|c|c|c|c|}
\hline Патологія & $\begin{array}{c}1 \text { група } \\
(n=35)\end{array}$ & $\begin{array}{c}2 \text { група } \\
(n=30)\end{array}$ & $\mathbf{p}$ \\
\hline Атріовентрикулярна комунікація & 4 & 3 & $>0,05$ \\
\hline $\begin{array}{l}\text { Частковий аномальний дренаж } \\
\text { легеневих вен }\end{array}$ & 3 & 2 & $>0,05$ \\
\hline $\begin{array}{l}\text { Дефект міжшлуночкової пере- } \\
\text { городки з високою легеневою } \\
\text { гіпертензією }\end{array}$ & 12 & 14 & $>0,05$ \\
\hline Стеноз легеневої артерії & 8 & 5 & $>0,05$ \\
\hline $\begin{array}{l}\text { Дефект міжшлуночкової пере- } \\
\text { городки в поєднанні з дефектом } \\
\text { міжпередсердної перегородки }\end{array}$ & 8 & 6 & $>0,05$ \\
\hline
\end{tabular}

міжпередсердної перегородки

Мета дослідження - оцінити вплив раннього ентерального харчування на перебіг післяопераційного періоду (тривалість штучної вентиляції легень (ШВЛ), частоту виникнення вентилятор-асоційованої пневмонії (ВАП), частоту зміни антибактеріальної терапії, призначення альбуміну, час перебування в палаті інтенсивної терапії) у дітей до 1 року після корекції вроджених вад серця в умовах екстракорпорального кровообігу.

Матеріали та методи. За 2013-2016 pp. в НІССХ імені М. М. Амосова НАМН дітям першого року життя з ВВС проведено 167 оперативних втручань на серці зі штучним кровообігом. Із цих дітей було ретроспективно досліджено дві групи пацієнтів. Анатомічна характеристика патології цих груп представлена в табл. 1.

У першій групі (35 осіб) у зв'язку зі зниженням кровообігу кишечника та синдромом малого серцевого викиду ентеральне харчування починали через 24 години, після стабілізації гемодинаміки і появи перистальтики. У другій групі ( 30 осіб) ентеральне харчування починали через 6 годин після операції через назогастральний зонд, з подальшим збільшенням обсягу харчування протягом доби до розрахункової потреби на даного пацієнта.

Були виключені пацієнти з вихідною патологією шлунково-кишкового тракту, мальабсорбцією і мальдигестією. Групи були порівнянні за зростом, віком, обсягом хірургічного втручання, часом перетискання аорти та тривалості штучного кровообігу (табл. 2).

У першій групі 16 пацієнтів і у другій групі 12 мали гіпотрофію І ступеня.

Для того щоб стан дитини визначався як гіпотрофія I ступеня, використовувалися поєднані критерії: загальний стан дитини - практично не страждає; симптоми: помірне рухове занепокоєння, легка блідість шкірних покривів; психомоторний розвиток відповідає віку; витончення підшкірно-жирової клітковини; в ділянці пупка складка досягає $0,8-1,0$ см; маса тіла знижена на 10-20\% від належної; імунологічна реактивність та толерантність до їжі - не змінені; в білковому спектрі можлива гіпопротеїнемія [7].

Для ентерального харчування використовувалися спеціальні суміші. До переваг даних сумішей відносять білок, представлено в них гідролізатом сироваткових білків, які характеризуються великою швидкістю евакуації зі шлунка і швидкою абсорбцією в кишечнику. Суміші мають низьку осмолярність, що забезпечує оптимальне навантаження на нирки дитини; вони містять холін, L-карнітин, селен, таурин, вітаміни та мікроелементи.

Критеріями оцінки впливу раннього ентерального харчування на метаболізм були біохімічні показники: загальний білок, альбумін, сечовина, креатинін до операції і на 1, 2, 5 та 10-ту добу після операції (табл. 3).

Перебіг післяопераційного періоду оцінювали за такими критеріями: тривалість ШВЛ, частота виникнення ВАП, частота зміни антибактеріальної терапії, призначення альбуміну, а також час перебування в палаті інтенсивної терапії.

Результати та обговорення. До найбільших змін після впливу післяопераційного стресу схильний білковий обмін. Аналізуючи результати біохімічних досліджень, можна відзначити, що загальний білок знижувався в обох групах. Але в групі 2, де ентеральне харчування починали в ранньому післяопераційному періоді, на другу добу спостерігається відновлення загального білка до вихідних значень $(\mathrm{p}=0,01)$. У групі 1 загальний білок упродовж десяти діб після операції залишався на нижчому рівні порівняно з другою групою $(\mathrm{p}<0,05)$ (табл. 3).

Рівень альбуміну суттєво відрізнявся в групах тільки в першу добу післяопераційного періоду $(\mathrm{p}=0,02)$ (табл. 3).

Таблиця 2

Характеристика досліджуваних груп

\begin{tabular}{|c|c|c|c|c|c|}
\hline Група & $\begin{array}{l}\text { Bik } \\
\text { (Mic.) }\end{array}$ & $\begin{array}{l}\text { Маса тіла } \\
\text { (кг) }\end{array}$ & $\begin{array}{l}\text { Тривалість } \\
\text { ІК (хв.) }\end{array}$ & $\begin{array}{l}\text { Час перетискання } \\
\text { аорти (хв.) }\end{array}$ & $\begin{array}{c}\text { Гіпотрофія } 1 \text { ступеня/ } \\
\text { нормотрофія (осіб) }\end{array}$ \\
\hline 1 група (n=35) & $\begin{array}{c}6,0 \\
(5,0-7,0)\end{array}$ & $\begin{array}{c}7,5 \\
(6,0-8,0)\end{array}$ & $\begin{array}{c}57,50 \\
(56,00-65,00)\end{array}$ & $\begin{array}{c}38,00 \\
(35,00-42,00)\end{array}$ & $16 / 19$ \\
\hline \multirow[t]{2}{*}{2 група (n=30) } & $\begin{array}{c}6,0 \\
(4,0-7,0)\end{array}$ & $\begin{array}{c}7,0 \\
(6,0-8,0)\end{array}$ & $\begin{array}{c}60,00 \\
(54,00-65,00)\end{array}$ & $\begin{array}{c}35,00 \\
(27,00-38,00)\end{array}$ & $12 / 18$ \\
\hline & $p>0,05$ & $p>0,05$ & $p>0,05$ & $p>0,05$ & $p>0,05$ \\
\hline
\end{tabular}




\section{Таблиця 3}

Результати лабораторних досліджень

\begin{tabular}{|c|c|c|c|c|c|}
\hline & Група & Загальний білок (г/л) & Альбуміни (г/л) & Креатинін (ммоль/л) & Сечовина (ммоль/л) \\
\hline \multirow{3}{*}{ До операції } & 1 & $\begin{array}{c}62,50 \\
(60,00-64,00)\end{array}$ & $\begin{array}{c}31,15 \\
(30,30-32,10)\end{array}$ & $\begin{array}{c}0,085 \\
(0,070-0,100)\end{array}$ & $\begin{array}{c}5,750 \\
(5,600-6,100)\end{array}$ \\
\hline & 2 & $\begin{array}{c}64,00 \\
(62,00-65,00)\end{array}$ & $\begin{array}{c}32,55 \\
(31,50-33,40)\end{array}$ & $\begin{array}{c}0,085 \\
(0,070-0,110)\end{array}$ & $\begin{array}{c}5,800 \\
(5,600-6,100)\end{array}$ \\
\hline & & $p>0,05$ & $p>0,05$ & $p>0,05$ & $p>0,05$ \\
\hline \multirow{3}{*}{ 1-ша доба } & 1 & $\begin{array}{c}60,00 \\
(50,00-62,00)\end{array}$ & $\begin{array}{c}31,45 \\
(30,60-32,40)\end{array}$ & $\begin{array}{c}0,075 \\
(0,060-0,090)\end{array}$ & $\begin{array}{c}7,800 \\
(6,800-10,90)\end{array}$ \\
\hline & 2 & $\begin{array}{c}63,00 \\
(62,00-64,00)\end{array}$ & $\begin{array}{c}32,80 \\
(32,20-34,60)\end{array}$ & $\begin{array}{c}0,075 \\
(0,060-0,090)\end{array}$ & $\begin{array}{c}6,750 \\
(6,500-7,500)\end{array}$ \\
\hline & & $p=0,01$ & $p=0,02$ & $p>0,05$ & $p=0,02$ \\
\hline \multirow{3}{*}{ 2-га доба } & 1 & $\begin{array}{c}61,50 \\
(53,00-63,00)\end{array}$ & $\begin{array}{c}33,80 \\
(32,40-34,60)\end{array}$ & $\begin{array}{c}0,090 \\
(0,080-0,100)\end{array}$ & $\begin{array}{c}12,65 \\
(11,90-13,60)\end{array}$ \\
\hline & 2 & $\begin{array}{c}64,00 \\
(63,00-65,00)\end{array}$ & $\begin{array}{c}34,60 \\
(34,20-35,60)\end{array}$ & $\begin{array}{c}0,085 \\
(0,080-0,100)\end{array}$ & $\begin{array}{c}9,00 \\
(7,500-10,50)\end{array}$ \\
\hline & & $p=0,01$ & $p>0,05$ & $p>0,05$ & $p=0,03$ \\
\hline \multirow{3}{*}{ 5-та доба } & 1 & $\begin{array}{c}64,00 \\
(63,00-65,00)\end{array}$ & $\begin{array}{c}33,20 \\
(31,40-34,50)\end{array}$ & $\begin{array}{c}0,080 \\
(0,070-0,090)\end{array}$ & $\begin{array}{c}8,150 \\
(6,500-8,900)\end{array}$ \\
\hline & 2 & $\begin{array}{c}66,00 \\
(65,00-67,00)\end{array}$ & $\begin{array}{c}34,60 \\
(33,70-34,90)\end{array}$ & $\begin{array}{c}0,080 \\
(0,070-0,090)\end{array}$ & $\begin{array}{c}6,400 \\
(5,800-6,700)\end{array}$ \\
\hline & & $p=0,002$ & $p>0,05$ & $p>0,05$ & $p=0,01$ \\
\hline \multirow{3}{*}{ 10-та доба } & 1 & $\begin{array}{c}63,00 \\
(62,00-64,00) \\
\end{array}$ & $\begin{array}{c}32,85 \\
(32,50-33,60) \\
\end{array}$ & $\begin{array}{c}0,080 \\
(0,075-0,090) \\
\end{array}$ & $\begin{array}{c}7,150 \\
(6,500-7,400)\end{array}$ \\
\hline & 2 & $\begin{array}{c}64,50 \\
(63,00-65,00)\end{array}$ & $\begin{array}{c}34,65 \\
(33,70-34,70)\end{array}$ & $\begin{array}{c}0,082 \\
(0,070-0,090)\end{array}$ & $\begin{array}{c}6,400 \\
(5,800-6,700)\end{array}$ \\
\hline & & $p=0,05$ & $p>0,05$ & $p>0,05$ & $p>0,05$ \\
\hline
\end{tabular}

Показники креатиніну у групах не відрізнялися $(\mathrm{p}>0,05)$ і знаходилися в межах допустимих значень, що вказує на відсутність ниркової патології в даного контингенту хворих.

За результатами аналізу сечовина підвищувалася в обох групах, але в першій групі рівні цього лабораторного показника значущо вищі, ніж у групі з використанням раннього ентерального харчування $(\mathrm{p}<0,05)$, а нормалізація показників відбувалася тільки на 10-ту добу післяопераційного періоду, що вказує на суттєві катаболічні зміни в першій групі.

Як зазначено в роботі [8], вплив раннього ентерального харчування на імунну, бар'єрну та метаболічну функції запобігає бактеріальній транслокації. Хоча, з іншого боку, час респіраторної підтримки є важли-

\section{Таблиця 4}

Клінічні критерії

\begin{tabular}{ccc} 
Група & Частота ВАП & $\begin{array}{c}\text { Частота зміни } \\
\text { антибіотикотерапії }\end{array}$ \\
\hline 1 & $12 / 16$ & $10 / 35$ \\
\hline 2 & $2 / 12$ & $4 / 30$ \\
\hline & $\mathrm{p}=0,03$ & $\mathrm{p}=0,03$
\end{tabular}

вим фактором ризику розвитку ВАП [9]. Можливо, у зв'язку із цим у другій групі значушо меншою була частота виникнення вентилятор-асоційованої пневмонії і рідше була потрібна зміна антибіотикотерапії (табл. 4).

ШВЛ була суттєво коротша в групі, де використовувалося раннє ентеральне харчування, що статистично значущо скорочувало перебування пацієнтів у палаті інтенсивної терапії (ПІТ) (табл. 5).

При недостатньому харчовому статусі не тільки відбувається зниження толерантності організму до фізичних навантажень, а й виникає м'язова гіпотонія на тлі порушення обміну білка, що, у свою чергу, призводить до збільшення часу ШВЛ і перешкоджає переведенню даної категорії пацієнтів на самостійне дихання. У табл. 5 представлено дані про частоту вентилятор-

\section{Таблиця $\mathbf{5}$}

Терміни активізації хворих після операції

\begin{tabular}{ccc} 
Група & ШВЛ (годин) & $\begin{array}{c}\text { Госпіталізація в ПІт } \\
\text { (годин) }\end{array}$ \\
\hline 1 & $24,50(20,00-29,00)$ & $82,00(70,00-94,00)$ \\
\hline 2 & $6,00(4,00-8,00)$ & $25,00(22,00-28,00)$ \\
\hline$p$ & 0,03 & 0,04
\end{tabular}


асоційованої пневмонії в післяопераційному періоді у дітей із гіпотрофією 1-го ступеня. Очевидно, що ці діти, з вихідним порушенням харчового статусу, а також з пізнім початком ентерального харчування, більш схильні до таких ускладнень, як ВАП.

Висновки. Використання раннього ентерального харчування дозволяє забезпечити адекватний синтез білка (особливо при початковій гіпотрофії), скоротити кількість випадків виникнення вентилятор-асоційованої пневмонії, знизити частоту зміни антибіотикотерапії і часу перебування на ШВЛ, що сприяє швидкій активізації та скорочує час перебування дитини в палаті інтенсивної терапії.

\section{Література}

1. Зиньковский М. Ф. Врожденные пороки сердца: монография / М. Ф. Зиньковский. - К. : Книга-плюс, 2010. $-37 \mathrm{c}$.

2. Оценка питательного статуса у детей: пособие для врачей / Под ред. Л. Е. Цыпина, А. А. Корсунского. - М. : РГМУ, 2005. - 44 c.

3. Парентеральное и энтеральное питание: национальное руководство / Под ред. М. Ш. Хубутия, Т. С. По- новой, А. И. Салтанова. - М. : ГЭОТАР-Медиа, 2014. $-800 \mathrm{c}$.

4. Миролюбов Л. М. Врожденные пороки сердца у новорожденных и детей первого года жизни. - Казань : Медицина, 2008. - 152 с.

5. Ентеральне зондове харчування в ранньому післяопераційному періоді та профілактика його кишкових ускладнень / В. М. Короткий, І. В. Колосович, П. В. Чемоданов // Клінічна хірургія. - 2012. - № 4. $23 \mathrm{c}$.

6. Лечебное питание детей с хирургической патологией в раннем послеоперационном периоде / Ю. В. Ерпулева // Лечащий врач. - 2010. - № 6. - 78-79 с.

7. Лейдерман И. Н. Современные аспекты периоперативной нутритивной поддержки // Анестезиология и реаниматология. - 2000. - № 3. - С. 56-59.

8. Мошківська Л. В., Хеміо Арнес С. Г. Роль цитокінів у прогнозуванні післяопераційних ускладнень у дітей // Вісник серцево-судинної хірургії. - 2016. - № 2. C. $79-82$.

9. Ventilator-associated pneumonia in children after cardiac surgery in The Netherlands / Roeleveld P. P., Guijt D., Kuijper E. J. et al. // Intensive Care Med. - 2012. Vol. 37. - P. 1656-1663.

\title{
The early enteral feeding in postoperative period and its influence on recovery of children under the age of 1 year after cardiac surgery
}

\author{
Yakimishen E., Boyko S., Khemio Arnes S., Moshkivska L., Truba Y., Lazoryshynetz V. \\ National M. M. Amosov Institute of Cardiovascular Surgery National Academy of Medical Sciences of Ukraine (Kyiv)
}

Aim: determination of postoperative period progress in patients under the age of 1 year after cardiac surgery depending of the time of beginning of enteral feeding. Methods: retrospective analysis of two groups of patients under the age of 1 year which received enteral feeding during the first 24 hours (1st group) and during the first 6 hours (2nd group) after cardiac surgery. Evaluation criteria were: biochemical indicators, postoperative progress and the time of stay in ICU. Results: as a result of the study significant catabolic changes in the 1st group of patients (with late start of enteral feeding) were identified. The postoperative period progress was more favorable, the time of stay in ICU was shorter in the 2nd group. Conclusion: Early enteral feeding decreases the risk of development of postoperative respiratory complications, the frequency of antibacterial therapy changes, the albumin administration and reduces the activation time after cardiac surgery with cardiopulmonary bypass.

Key words: enteral feeding, newborns, congenital heart diseases, cardiac surgery, cardiopulmonary bypass.

\section{Раннее энтеральное питание в послеоперационном периоде и его влияние на активизацию детей до 1 года после кардиохирургических операций}

\author{
Якимишен Е. А., Бойко С. Н., Хемио Арнес С. Г., Мошковская Л. В., Труба Я. П., Лазоришинец В. В. \\ ГУ «Национальный институт сердечно-сосудистой хирургии имени Н. М. Амосова НАМН» (Киев)
}

Цель исследования - определение характера течения послеоперационного периода у кардиохирургических пациентов в возрасте до 1 года в зависимости от времени начала энтерального питания. Методы. Проведено ретроспективное исследование двух групп детей в возрасте до 1 года, у которых энтеральное питание начато через 24 часа (группа 1) и через 6 часов (группа 2) после операции на сердце. Критериями оценки были биохимические показатели, течение послеоперационного периода и время пребывания в палате интенсивной терапии. Результаты. Существенные катаболические изменения выявлены в группе 1 (с поздним началом энтерального питания). Течение послеоперационного периода было более благоприятным, время пребывания в палате интенсивной терапии меньшим, чем в группе 2. Выводы. Раннее энтеральное питание уменьшает риск развития послеоперационных респираторных осложнений, частоту смены антибактериальной терапии, назначение альбумина и сокращает время активизации пациентов после операций на сердце с применением экстракорпорального кровообращения.

Ключевые слова: энтеральное питание, новорожденные, врожденные пороки сердиа, кардиохирургические операиии, искусственное кровообращение. 